\title{
Interoperability calls for an unusual mix of skills
}

\author{
Computer-science expertise will be a key ingredient of a successful 'bioinformatics nation'.
}

Sir — Lincoln Stein, in his Commentary (Nature 417, 119-120; 2002), argues that a web-services technology and a few agreed guidelines could help organize "a bioinformatics nation". But can one technology be the ultimate solution for interoperability problems? I think it unlikely.

Although web services can be successfully leveraged for bioinformatics, similar claims were made not so long ago for CORBA (common object request broker architecture; www.omg.org). Until $\mathrm{XML}$ and web services appeared on the scene, many believed - I among them that CORBA would be the technology of choice to solve interoperability problems in bioinformatics. It was already available five years ago. Notable efforts, from both industry and academic institutions, have been invested to create standards for the life sciences (see, for example, www.omg. org/technology/documents/formal/omg lsr_specs.htm). Nevertheless, CORBA was insufficient to solve the interoperability problems that continue to challenge bioinformaticians.

Interoperability among biological databases and tools is a complex problem, only remotely influenced by a given technology, or by the fact that bioinformaticians may not follow what Stein calls a "data provider's code of conduct". For instance, I believe that interoperability is also limited by discipline-related factors. Today's bioinformaticians have been trained primarily in scientific backgrounds (biology, chemistry, physics, mathematics and so on) that prepared them well for many topics in bioinformatics, but left them lacking sufficient knowledge of computer-science methods. The result is that bioinformaticians sometime ignore elementary design principles routinely applied by software engineers. The lack of interoperability among the tools, and the databases built by this community, to some extent reflect the heterogeneity of the backgrounds in the community itself. I think that reversing this tendency will involve more than the steps suggested by Stein.

In particular, significant investments will be required to provide students with a multidisciplinary education that adds computer science and software engineering to their curriculum. In the short term, multidisciplinary teams can be assembled that bring together scientists and engineers. A cultural clash can be expected, but isn't this the main challenge of interoperability?

Fabien Campagne

Institute for Computational Biomedicine, Mount Sinai School of Medicine, 1 Gustave L. Levy Place, Box 1218, New York, New York 10029, USA

\section{Rebel army need not be a barrier to conservation}

Sir - We welcome your highlighting of conservation problems in the Visayan region in the News story "Conservationists under fire in the Philippines" (Nature 416, 669 ; 2002) profiling the work of the Philippine Endemic Species Conservation Project (PESCP). But it is disappointing that the security issues raised were not given appropriate context and explanation.

Your article implied, on the strength of one incident, that Negros Island is unsafe for tropical-forest conservation work. This is not the case. The local opposition to the PESCP on Panay Island that you report may reflect differences in campaigning style, as this is not our experience for non-campaigning organizations on Negros Island. The armed group who confronted the PESCP is likely to belong to the Revolutionary Proletarian Army - Alex Boncayao Brigade (RPA-ABB), whose agenda is political, not conservation-orientated. The incident probably arose from a lack of awareness by both parties.

Coral Cay Conservation has been working on Negros Island for seven years. It has deployed, without opposition, more than 2,000 volunteer field personnel to several areas including, for the past three years, the North Negros Forest Reserve (where the PESCP was located) as part of the community-based Negros Rainforest
Conservation Project (NRCP). Personnel often work from satellite camps in the forest and have met no hostility.

Security is an important concern, as the RPA-ABB has members based in and around the North Negros Forest Reserve. Their lack of hostility towards NRCP people probably reflects the fact that they know who we are and what we're doing. The successful and unhindered efforts of the NRCP have been aided by communication at all levels. Coral Cay Conservation liaises closely with the British Embassy and the Foreign and Commonwealth Office, but it also works in partnership with a local group, the Negros Forests and Ecological Foundation, engaging all stakeholders (government, non-government and local communities) in the area, including the RPA-ABB.

Local stakeholders are keen to increase conservation activity on Negros Island. So, although it is important to promote the work of PESCP, it is also vital to address security issues in a local context. Craig Turner, Pete Raines Coral Cay Conservation, The Tower, 125 High Street, Colliers Wood, London SW19 2JG, UK

\section{Jury out on Jefferson's alleged descendants}

Sir - Your News report " "Jefferson's descendants continue to deny slave link" states that Thomas Jefferson's descendants have decided that the descendants of his slave Sally Hemings cannot join their family club, despite DNA evidence published in Nature suggesting that he fathered at least one of her children. In fact, that evidence suggests no specific Jefferson. The story also asserts that insistence on conclusive proof that the father was Thomas "cuts no ice" in academia. In fact, 13 noted scholars from 12 universities reviewed the historical and DNA evidence and unanimously found the paternity "by no means proven"2. This 'Scholars Commission' - convened by the Thomas Jefferson Heritage Society but acting independently — criticized Nature for fostering misunderstanding of DNA evidence in the wider historical debate.

Steven T. Corneliussen

Thomas Jefferson National Accelerator Facility, 12000 Jefferson Avenue, Newport News, 23606 Virginia, USA

1. Check, E. Nature 417, 213 (2002).

2. The Jefferson-Hemings Scholars Commission Report on the Jefferson-Hemings Matter, 12 April 2001, www.geocities.com/tishcommission

(to be published by Carolina Academic Press).

Correction There was an error in the first sentence of ref. 1. The word 'ancestors' was mistakenly used instead of 'descendants'. The sentence should have read: "Thomas Jefferson's descendants have decided that the descendants of one of his slaves cannot join their family club..." 